\title{
Relationship between Surface Characteristics and Floatability in Representative Sulfide Minerals: Role of Surface Oxidation
}

\author{
Gilsang Hong ${ }^{1}$, Junhyun Choi ${ }^{1}$, Yosep Han ${ }^{1}$, Kwang-Suk Yoo ${ }^{2}$, Kwanho Kim², Sang Bae Kim ${ }^{2}$,* \\ and Hyunjung $\mathrm{Kim}^{1, *}$
}

${ }^{1}$ Department of Mineral Resources and Energy Engineering, Chonbuk National University,

567, Baekje-daero, Deokjin-gu, Jeonju, Jeonbuk 54896, Republic of Korea

${ }^{2}$ Korea Institute of Geoscience and Mineral Resources, 124, Gwahak-ro, Yuseong-gu, Daejeon, 34132, Republic of Korea

\begin{abstract}
This study investigates how changes in the surface properties of three representative sulfide minerals (galena, sphalerite and chalcopyrite) affect their floatability in the presence of an oxidizing agent $\left(\mathrm{H}_{2} \mathrm{O}_{2}\right)$. Tests were conducted at four molar ratios of $\mathrm{H}_{2} \mathrm{O}_{2}$ :mineral $(0,0.5$, 1.0 , and 2.0). To better capture the effect of surface oxidation, the tests were conducted at both acid and basic conditions (i.e., $\mathrm{pH}=3$ and 10 ). In all surface property and floatability evaluations, the $\mathrm{pH}$ and Eh were equilibrated. The surface properties were evaluated by X-ray diffraction, Fourier transform infrared spectroscopy, zeta potential measurements and contact angle analyses. The floatability was evaluated by a microflotation method. At the acidic initial $\mathrm{pH}$, galena most sensitively reacted with $\mathrm{H}_{2} \mathrm{O}_{2}$, followed by chalcopyrite and sphalerite, whereas at $\mathrm{pH} 10$, the reactivity differences were insignificant. $\mathrm{H}_{2} \mathrm{O}_{2}$ addition changed the sulfide species (initially present on the mineral surface) to sulfate or hydroxyl species, and decreased the mineral floatability. To investigate the surface property that mainly reduced the mineral floatability in the presence of $\mathrm{H}_{2} \mathrm{O}_{2}$, we measured the zeta potentials and contact angles, which are closely associated with the electrostatic and hydrophobic forces, respectively. The floatability depended on the contact angle after the $\mathrm{H}_{2} \mathrm{O}_{2}$ addition, implying that the floatability was mainly reduced through oxidation reactions, which increased the hydrophilicity of the mineral surface. [doi:10.2320/matertrans.M2017014]
\end{abstract}

(Received January 13, 2017; Accepted April 5, 2017; Published April 28, 2017)

Keywords: $\quad$ sulfide mineral, floatability, surface oxidation, hydrophobicity

\section{Introduction}

The development of efficient flotation processes of copper, lead, and zinc complex sulfide minerals is a challenging but interesting task. ${ }^{1,2)}$ In particular, the sulfide minerals (e.g., chalcopyrite, galena, and sphalerite) associated with the subject metal possess similar surface properties (e.g., electrokinetic and hydrophobic properties). ${ }^{3-9)}$ Fullston and the colleagues reported that the electrokinetic property of intact sulfide minerals such as pyrite, sphalerite, chalcopyrite, and galena is similar with that of elemental sulfur, and thus they have similar isoelectric points lower than $3 .^{3,4)}$ Depending on the magnitude of polarity (i.e., the strength of bonding composed of minerals), minerals can be subdivided into five categories; ${ }^{5)}$ sulfide minerals have a weak covalent bonding that is relatively weaker than that of carbonate, sulfate, and oxide minerals, and the low surface polarity caused by the weak bonding structure renders the surface of sulfides relatively hydrophobic.

For flotation recovery and grade improvement, the surface of metallic minerals that need to be recovered must be made hydrophobic while others must be hydrophilic. ${ }^{9-11)}$ However, due to the aforementioned reasons that sulfide minerals possess similar surface properties, separating each other is not straightforward. In most studies, hence, the recovery and grade have been improved by introducing effective or novel depressants. ${ }^{12-20)}$ Various inorganic salts and organic polymers such as dextrin, starch, carboxymethyl cellulose, ferrochrome lignosulfonate, potassium dichromate, sodium humate, ammonium persulfate have been introduced as a depressant in complex sulfide mineral flotation processes. ${ }^{12-16)}$ For instance, Rath and Subramanian reported that galena can be effectively depressed using dextrin in the $\mathrm{pH}$ range of 10 to 12 and sphalerite recovery can be improved to $85 \% .^{13)}$ The combined use of sodium humate and ammonium persulfate has been found as an efficient depressant of galena in flotation separation for copper/lead bulk concentrate. ${ }^{14)}$ Tapley and Yan found that magnesium-ammonium mixture can be used as an arsenopyrite depressant from a pyrite-arsenopyrite system with sodium ethyl xanthate as a collector; the best separation was achieved at a $\mathrm{pH}$ of 8 and $250 \mathrm{mg} / \mathrm{L}$ magnesium-ammonium mixture. ${ }^{15)}$ The diverse types of depressants suggest that when separating complex sulfide minerals, an appropriate depressant for the specific sulfide mineral must be selected and optimized. ${ }^{12-20)}$

Depressants often work by changing surface properties via surface oxidation and polymer adsorption, which interferes with bubble attachment. ${ }^{18,19)}$ When a collector is required, changed surface properties interfere with collector attachment, and eventually prohibits bubble attachment. ${ }^{19,20)}$ Thus, it is essential to interpret the changes in surface properties during reaction with depressants, and to understand their consequent correlations with floatability. This study, therefore, aims to correlating the surface property changes with the floatabilities of copper, lead, and zinc sulfide minerals subjected to varying extents of surface oxidation. Hydrogen peroxide $\left(\mathrm{H}_{2} \mathrm{O}_{2}\right)$ was employed as a depressant in the present study. The surface properties were investigated by Fourier transform infrared spectroscopy (FT-IR), X-ray diffraction (XRD), and zeta potential and goniometer measurements. The floatability was evaluated through microflotation tests. The outcomes of this study provide basic information for the efficient flotation processing of lead, zinc, and copper complex sulfide minerals. 


\section{Materials and Methods}

\subsection{Minerals and reagents}

The sulfide minerals were galena $(\mathrm{PbS})$, sphalerite $(\mathrm{ZnS})$, and chalcopyrite $\left(\mathrm{CuFeS}_{2}\right)$, purchased from Ward's Science. The mineralogy and chemical composition of these minerals were investigated by XRD (X'pert Pro, PANalytical, Netherlands), inductively coupled plasma (ICP) (iCAP 7000 Series ICP-OES, Thermo Fisher SCIENTIFIC, USA), and energy dispersive X-ray fluorescence spectrometry (ED-XRF) (Epsilon 5, PANalytical, Almero, The Netherlands). The purities of the tested $\mathrm{PbS}, \mathrm{ZnS}$, and $\mathrm{CuFeS}_{2}$ were $98.06 \%, 99.89 \%$, and $99.37 \%$, respectively (Table 1 and Fig. 1). For the flotation tests, the minerals were ground in a rod mill sized at $-100+$ 150 mesh (104-147 $\mu \mathrm{m}$, Tyler Standard). The ground sample was kept in a vacuum to prevent oxidation of the mineral surface. The oxidizing agent was 50 mass $\% \mathrm{H}_{2} \mathrm{O}_{2}$, and the $\mathrm{pH}$ regulators were $0.1 \mathrm{~N}$ hydrochloric acid $(\mathrm{HCl})$ and $0.1 \mathrm{~N}$ sodium hydroxide $(\mathrm{NaOH})$. All reagents were purchased from Sigma-Aldrich.

\subsection{Surface oxidation procedure}

To react the mineral with the oxidizing agent, $1 \mathrm{~g}$ mineral

Table 1 Chemical compositions of raw $\mathrm{PbS}, \mathrm{ZnS}$, and $\mathrm{CuFeS}_{2}$ used in this study.

\begin{tabular}{ccccccccccc}
\hline \multirow{2}{*}{ Minerals } & \multicolumn{10}{c}{ Chemical Composition (mass\%) } \\
\cline { 2 - 10 } & $\mathrm{S}$ & $\mathrm{Pb}$ & $\mathrm{Zn}$ & $\mathrm{Cu}$ & $\mathrm{Fe}$ & $\mathrm{Mn}$ & $\mathrm{Ag}$ & $\mathrm{Cd}$ & $\mathrm{Ni}$ \\
\hline $\mathrm{PbS}$ & 13.14 & 84.92 & - & - & 0.11 & - & - & - & - \\
$\mathrm{ZnS}$ & 32.87 & - & 67.02 & - & 0.02 & 0.01 & - & - & 0.01 \\
$\mathrm{CuFeS}_{2}$ & 34.73 & - & 0.96 & 34.40 & 30.24 & - & 0.30 & 0.05 & - \\
\hline
\end{tabular}
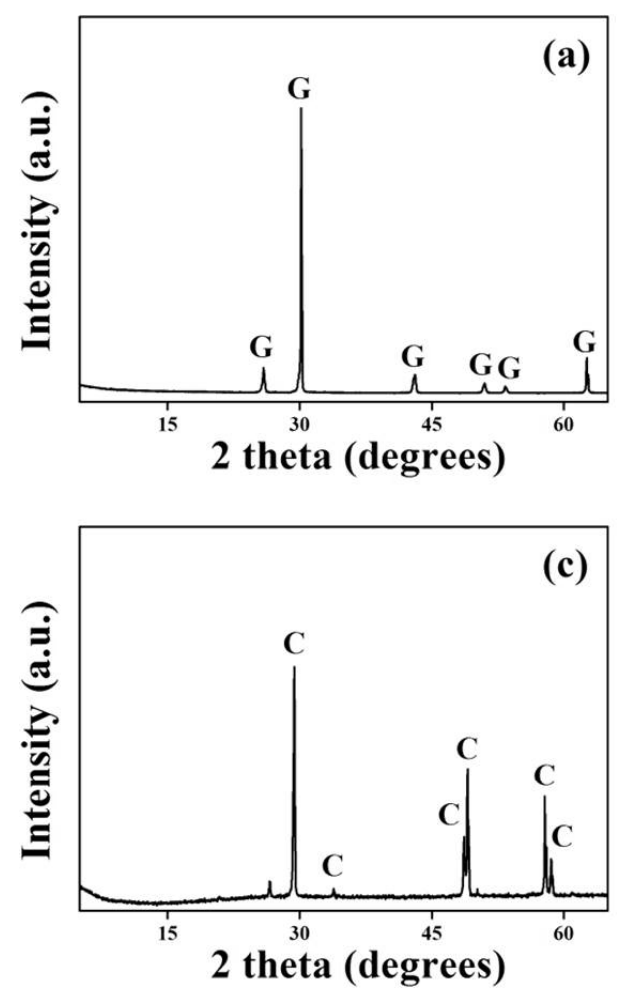

was added to $100 \mathrm{~mL}$ de-ionized (DI) water (Milli-Q Plus, Millipore Ltd., UK), then left for 90 minutes to equilibrate the reaction between the mineral and oxidizing agent. The mineral floatation and surface properties were investigated at different amounts of oxidizing agent (0, 0.5, 1.0, and 2.0 molar ratio of $\mathrm{H}_{2} \mathrm{O}_{2}$ to mineral). To better capture the effect of surface oxidation, the tests were conducted at both acid and basic conditions (i.e., $\mathrm{pH}=3$ and 10). Throughout the 90-minute oxidizing reaction, the $\mathrm{pH}$ and $\mathrm{Eh}$ were monitored at 10-minute intervals (Fig. 2). The $\mathrm{pH}$ and Eh were measured with a $\mathrm{pH}$ electrode (Orion Triode $\mathrm{pH} / \mathrm{ATC} \mathrm{Comb} \mathrm{Ag} / \mathrm{AgCl}$ Electrode, Thermo Science) and a ReDox electrode (Orion Sure-flow Comb Redox Eletrode, Thermo Science), respectively. Once the reaction was complete, the samples were filtered through a $0.45-\mu \mathrm{m}$ membrane filter (Advantec, Tokyo, Japan), then dried in a vacuum for 4 hours to prevent oxidation. The changes in the surface properties (mineralogy, zeta potential, and contact angle) and the floatability of the dried samples were investigated.

\subsection{Surface characterization}

\subsubsection{XRD and FT-IR analyses}

The variations of crystal structure and chemical bonding in $\mathrm{PbS}, \mathrm{ZnS}$, and $\mathrm{CuFeS}_{2}$ with different surface oxidation extents at the two pHs were investigated by XRD and FT-IR, respectively. First, the XRD patterns were recorded by an X'pert Pro, PANalytical using Ni-fibered $\mathrm{Cu} \mathrm{K} \alpha$ radiation $(\lambda=0.154606 \mathrm{~nm}, 40 \mathrm{kV}, 40 \mathrm{mV})$. The XRD patterns of the minerals were collected at $2 \theta=10-70^{\circ}$. The FT-IR spectra of the minerals were recorded by a JASCO FT/IR-4100 spectrometer in the range $2000-650 \mathrm{~cm}^{-1}$ at a resolution of $1.0 \mathrm{~cm}^{-1}$.

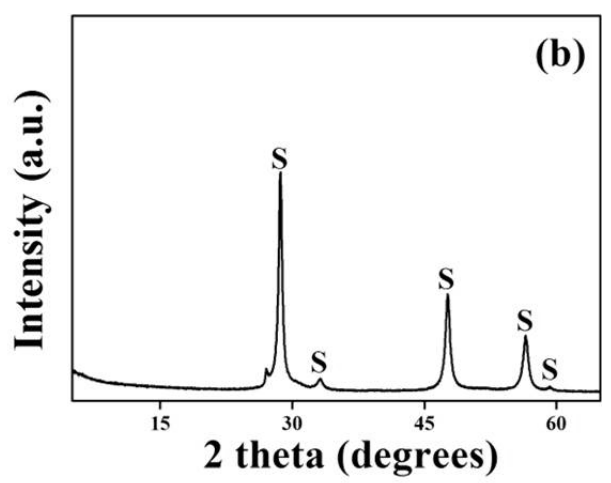

Fig. 1 XRD patterns of raw samples of (a) $\mathrm{PbS}$, (b) $\mathrm{ZnS}$, and (c) $\mathrm{CuFeS}_{2}$. The symbols G, S, and C denotes PbS, ZnS, and CuFeS 2 , respectively. 

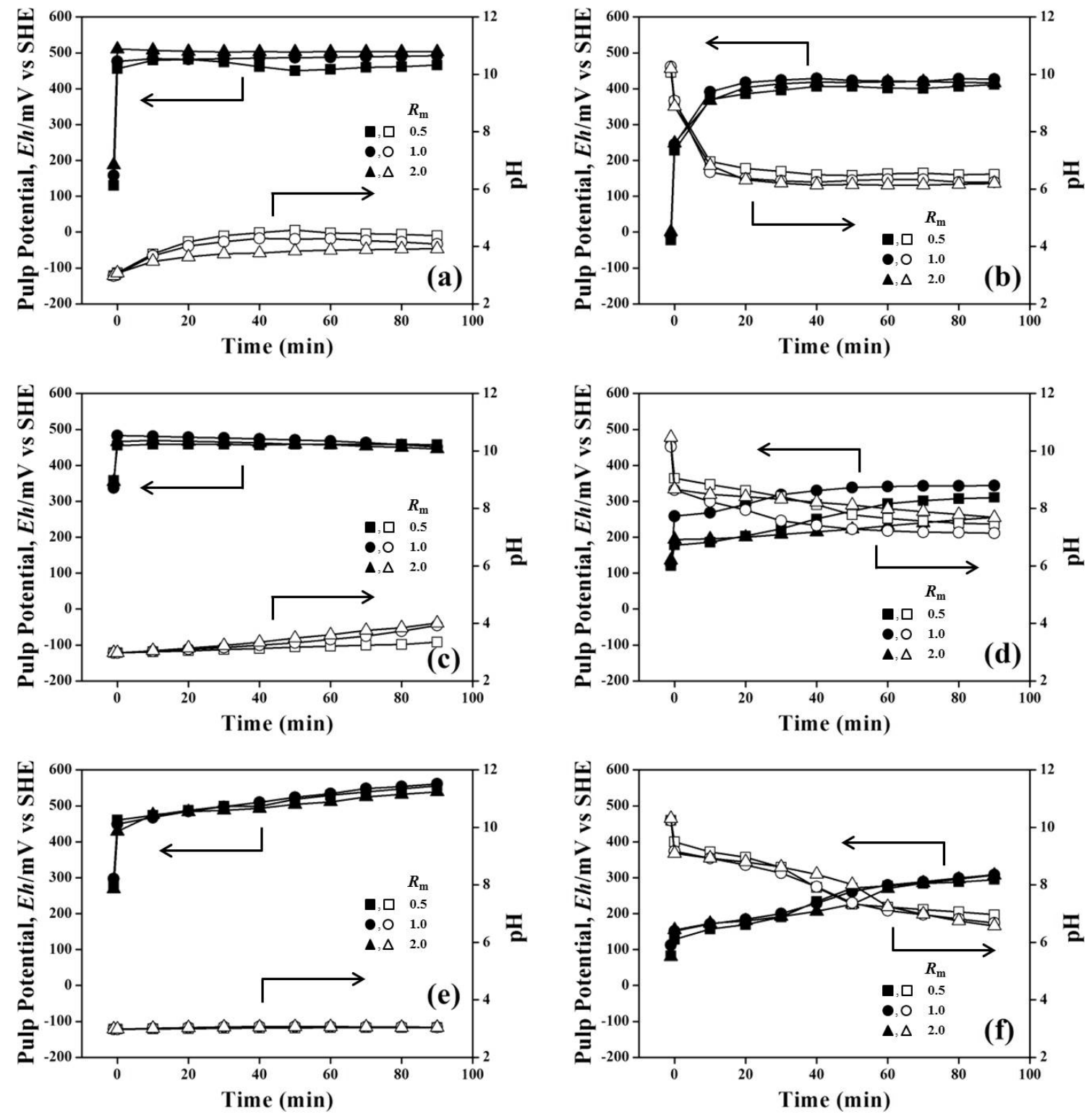

Fig. 2 Pulp pH and potential changes of $\mathrm{PbS}$ (a) and (b), $\mathrm{ZnS}$ (c) and (d), and $\mathrm{CuFeS}_{2}$ (e) and (f) treated with various $R_{\mathrm{m}}$ at initial $\mathrm{pH}$ of 3 (a), (c), and (e) and $10(\mathrm{~b}),(\mathrm{d})$, and (f). $R_{\mathrm{m}}$ represents the molar ratio of $\mathrm{H}_{2} \mathrm{O}_{2}$ to mineral.

\subsubsection{Zeta potential analysis}

The electrophoretic mobilities of $\mathrm{PbS}, \mathrm{ZnS}$, and $\mathrm{CuFeS}_{2}$ under the various experimental conditions (i.e., the four oxidation levels at two initial $\mathrm{pHs}$ ) were measured by a zeta potential analyzer (ELS-Z, Otsuka Eletronics Co., Japan). The samples for the mobility measurement were ground in a mortar, reacted with $\mathrm{H}_{2} \mathrm{O}_{2}$, and classified in deionized (DI) water. To minimize the gravitational effects during the mobility measurements, the size criterion in the classification was set to $3 \mu \mathrm{m}$. The classified product was then collected via centrifugation and re-suspended in DI water. The $\mathrm{pH}$ of the suspension was unadjusted (5.6-6.0). The mineral suspension was poured into the flow cell, and its electrophoretic mobility was measured. The values of at least 3 repeated measurements were converted to zeta potentials using the Smoluchowski equation. ${ }^{21,22)}$

\subsubsection{Contact angle measurement}

To examine the hydrophobicity of the $\mathrm{PbS}, \mathrm{ZnS}$, and $\mathrm{CuFeS}_{2}$ minerals surface-oxidized by different extents at two initial $\mathrm{pH}$ levels, the contact angles were measured with a goniometer (KRÜSS, Hamburg, Germany). In these measurements, the drop volume of the syringe was set to $0.2 \mu \mathrm{L}$, and the water was dispensed through a needle (NE60 with diameter $\Phi=0.212 \mathrm{~mm}$, KRÜSS, Germany).

\subsection{Microflotation tests}

Flotation tests were performed in well-controlled, modified Hallimond tubes containing $150 \mathrm{~mL}$ DI water and $1 \mathrm{~g}$ dried mineral stirred at $340 \mathrm{rpm}$ with a magnetic bar. During the flotation test (5 minutes), pure nitrogen gas (purity: $99.99 \%$ ) was injected at $30 \mathrm{~mL} / \mathrm{min}$. To evaluate the mineral floatability, floated and unfloated samples were dried at room temperature $\left(25^{\circ} \mathrm{C}\right)$ for 12 hours before their weight was measured. The percent floatability (f) was determined as $\mathrm{f}=\left(\mathrm{W}_{\mathrm{u}}\right)$ $\left.\left(\mathrm{W}_{\mathrm{f}}+\mathrm{W}_{\mathrm{u}}\right)\right) \times 100$. Here, $\mathrm{W}_{\mathrm{u}}$ and $\mathrm{W}_{\mathrm{f}}$, respectively, represent the weight of unfloated and floated samples. 


\section{Results and Discussion}

\subsection{Effect of $\mathrm{H}_{2} \mathrm{O}_{2}$ on mineral floatability}

Figure 3 (a) shows the floatability changes in $\mathrm{PbS}, \mathrm{ZnS}$, and $\mathrm{CuFeS}_{2}$ exposed to various $\mathrm{H}_{2} \mathrm{O}_{2}$ levels at initial $\mathrm{pH} 3$. In all minerals, the sulfide floatability tended to decrease with increasing $\mathrm{H}_{2} \mathrm{O}_{2}$ content. Interestingly, this tendency varied widely among the minerals. For instance, the floatability of $\mathrm{PbS}$ decreased to about $3.1 \%$ at a molar ratio of 0.5 , whereas that of $\mathrm{ZnS}$ remained at approximately $59.1 \%$ even at 2.0 molar ratio. The floatability of $\mathrm{CuFeS}_{2}$ was low at 2.0 molar ratio and similar to that of $\mathrm{PbS}$, but was less and more responsive to $\mathrm{H}_{2} \mathrm{O}_{2}$ content than the floatability of $\mathrm{PbS}$ and $\mathrm{ZnS}$, respectively.

Figure 3 (b) shows the floatability changes in $\mathrm{PbS}, \mathrm{ZnS}$, and $\mathrm{CuFeS}_{2}$ after $\mathrm{H}_{2} \mathrm{O}_{2}$ addition at initial $\mathrm{pH} 10$. As observed for initial $\mathrm{pH} 3$, the floatability levels of all sulfide minerals tended to decrease with increasing $\mathrm{H}_{2} \mathrm{O}_{2}$ content. However, the floatabilities were more sensitive to $\mathrm{H}_{2} \mathrm{O}_{2}$ addition at initial $\mathrm{pH} 10$ than at initial $\mathrm{pH} 3$. In particular, at 0.5 molar ratio, the floatability levels of the three mineral types decreased to $\sim 18 \%$ or lower. Again, $\mathrm{PbS}$ most sensitively reacted with $\mathrm{H}_{2} \mathrm{O}_{2}$, but its reactivity did not significantly differ from that of $\mathrm{ZnS}$ and $\mathrm{CuFeS}_{2}$.

\subsection{Effect of $\mathrm{H}_{2} \mathrm{O}_{2}$ on mineralogy}

To understand the floatability responses to $\mathrm{H}_{2} \mathrm{O}_{2}$ amounts described in subsection 3.1, the mineral surface properties that directly affected the floatability were investigated. First, the changes in mineral surface mineralogy before and after the $\mathrm{H}_{2} \mathrm{O}_{2}$ reaction were investigated by XRD and FT-IR.

Figure 4 shows the XRD and FT-IR results of $\mathrm{PbS}$ exposed to various $\mathrm{H}_{2} \mathrm{O}_{2}$ amounts at $\mathrm{pH} 3$ and $\mathrm{pH} 10 . \mathrm{PbS}$ tended to sensitively react within the range of investigated $\mathrm{H}_{2} \mathrm{O}_{2}$ amounts. A sulfate peak was observed at both $\mathrm{pHs}$, but an additional hydroxyl peak appeared at $\mathrm{pH} 10 .{ }^{23,24)}$ This implies that the oxidizing reaction changed the relatively hydrophobic sulfide layer, which was initially present on the $\mathrm{PbS}$ surface, to hydrophilic sulfate and hydroxyl layers. The XRD and FT-IR results of $\mathrm{ZnS}$ revealed no sulfate layer formation in the presence of $\mathrm{H}_{2} \mathrm{O}_{2}$ at $\mathrm{pH} 3$ (see Figs. 5 (a) and 5 (b)), but hydroxyl layers were observed in the $\mathrm{ZnS}$ IR spectra at $\mathrm{pH}$ $10^{25)}$ (Fig. 5 (d)). Note that as the $2 \theta$ values of $\mathrm{ZnS}$ and $\mathrm{Zn}(\mathrm{OH})_{2}$ are very similar $\left(47.59^{\circ}\right.$ and $47.60^{\circ}$, respectively), they are not clearly differentiated in the XRD analysis (Fig. 5 (c)). The non-distinguishable oxygen-associated peak at $\mathrm{pH} 3$ suggests that the $\mathrm{ZnS}$ surface is relatively insensitive to $\mathrm{H}_{2} \mathrm{O}_{2}$. Similar insensitive response to surface oxidation was also observed for $\mathrm{CuFeS}_{2}$ at pH 3 (Figs. 6 (a) and 6 (b)). On the other hand, the $\mathrm{H}_{2} \mathrm{O}_{2}$ reaction changed the initial sulfide layer of $\mathrm{CuFeS}_{2}$ to $\mathrm{Cu}(\mathrm{OH})_{2}$ at $\mathrm{pH} \mathrm{10}{ }^{26)}$ (Fig. $6(\mathrm{~d})$ ); note that the XRD analysis was less sensitive than the FT-IR analysis, so the $\mathrm{Cu}(\mathrm{OH})_{2}$ peak was not detected in the XRD results (Figs. 6 (c) versus 6 (d)).

\subsection{Causes of reduced floatability in the presence of $\mathrm{H}_{2} \mathrm{O}_{2}$}

As confirmed in subsection 3.2, the structure of the three sulfide minerals developed a high polarity after $\mathrm{H}_{2} \mathrm{O}_{2}$ addi-
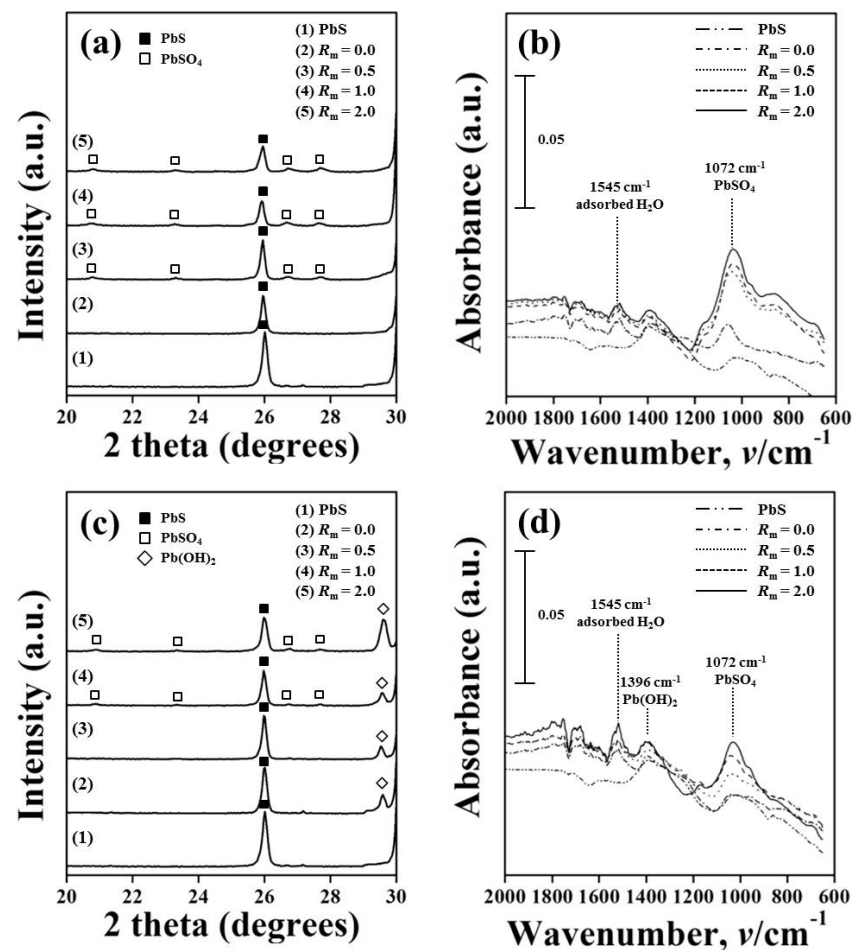

Fig. 4 XRD patterns and IR spectra of $\mathrm{PbS}$ treated with various $R_{\mathrm{m}}$ at initial $\mathrm{pH}$ of 3 (a) and (b) and 10 (c) and (d). The measurements were carried out under equilibrium conditions as shown in Fig. 2. The information of unreacted raw samples is also presented for guidance.
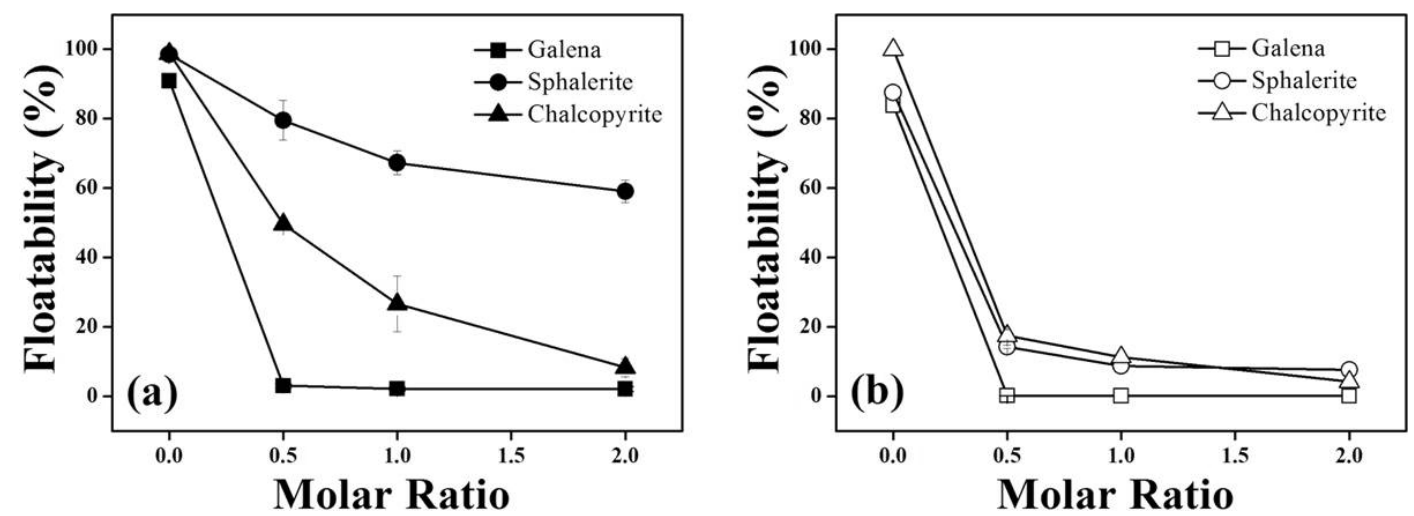

Fig. 3 Floatabilities of $\mathrm{PbS}, \mathrm{ZnS}$, and $\mathrm{CuFeS}_{2}$ treated with different molar ratios of $\mathrm{H}_{2} \mathrm{O}_{2}$ to mineral at initial $\mathrm{pH}$ of 3 (a) and 10 (b). The tests were carried out under equilibrium conditions as shown in Fig. 2. 

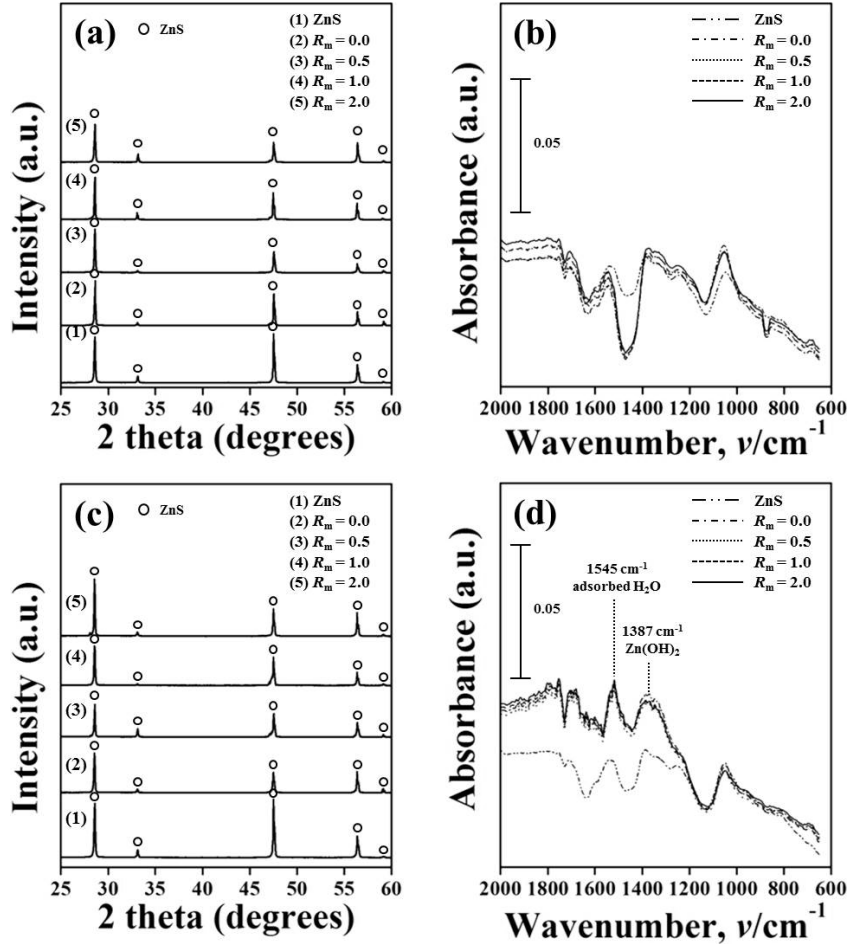

Fig. 5 XRD patterns and IR spectra of $\mathrm{ZnS}$ treated with various $R_{\mathrm{m}}$ at initial $\mathrm{pH} 3$ (a) and (b) and 10 (c) and (d). The measurements were carried out under equilibrium conditions as shown in Fig. 2. The information of unreacted raw samples is also presented for guidance.

tion. However, the trend of decreasing mineral floatability with increasing $\mathrm{H}_{2} \mathrm{O}_{2}$ amount was not sufficiently explained likely due to instrument detection limit. Mineral flotation is determined by the particle-bubble collisions, the attachment of particles to bubbles, and the stability of the attached particles. $^{27,28)}$ As the physical conditions in the present flotation tests were very similar (e.g., identical mixing speed, similar distributions of particle sizes), the particle-bubble collisions were assumed consistent among the mineral types and $\mathrm{H}_{2} \mathrm{O}_{2}$ contents. In addition, because the identical mixing speed ( $\sim 340 \mathrm{rpm})$ imparted the same external force to the attached particles, the stability of the attached particles was assumed consistent. Therefore, the mineral floatability is determined by the probability of particle attachment to the bubbles.

Particles and bubbles interact by van der Waals force, electrostatic force, and hydrophobic force. ${ }^{29,30)}$ The van der Waals force exerts a repulsive effect in the solid-liquid-bubble system, whereas the hydrophobic force is attractive and the electrostatic force is either repulsive or attractive depending on the condition. ${ }^{31,32)}$ As shown in subsection 3.2, $\mathrm{H}_{2} \mathrm{O}_{2}$ addition changes the surface mineralogy. This implies the potential changes in surface charge and hydrophobicity of minerals, which is related to the electrostatic force and hydrophobic force, respectively. The mineral zeta potentials of the samples treated with different $\mathrm{H}_{2} \mathrm{O}_{2}$ molar ratios are shown in Table 2. In this analysis, it was assumed that if the electrostatic force governs the bubble-mineral interaction, surface oxidation would increase the electrostatic repulsive force of the bubbleparticle interaction; otherwise, the trend would contradict the floatability trend observed in Fig. 3. The zeta potential of bubbles is known to be negative in circumneutral environ-
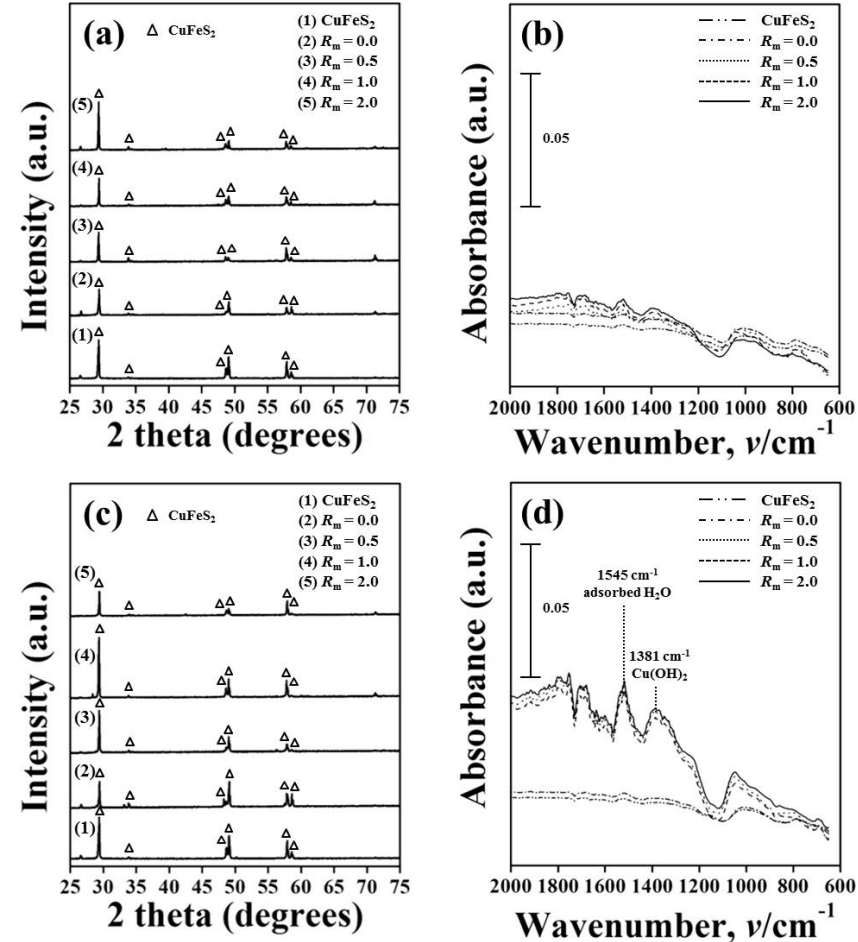

Fig. 6 XRD patterns and IR spectra of $\mathrm{CuFeS}_{2}$ treated with various $R_{\mathrm{m}}$ at initial pH 3 (a) and (b) and 10 (c) and (d). The measurements were carried out under equilibrium conditions as shown in Fig. 2. The information of unreacted raw samples is also presented for guidance.

Table 2 Zeta potentials of $\mathrm{PbS}, \mathrm{ZnS}$, and $\mathrm{CuFeS}_{2}$ treated with various $R_{\mathrm{m}}$ at initial $\mathrm{pH}$ of 3 and 10 . The measurements were carried out under equilibrium conditions (see Fig. 2).

\begin{tabular}{cccccc}
\hline \multirow{2}{*}{$\mathrm{pH}$ Mineral } & \multicolumn{5}{c}{$R_{\mathrm{m}}(-)^{* 1}$} \\
\cline { 2 - 6 } & & 0.0 & 0.5 & 1.0 & 2.0 \\
\hline & $\mathrm{PbS}$ & $-11.17 \pm 4.08$ & $9.44 \pm 2.24$ & $\mathrm{ND}^{* 2}$ & $\mathrm{ND}$ \\
3 & $\mathrm{ZnS}$ & $-7.50 \pm 3.54$ & $-19.90 \pm 1.22$ & $-21.19 \pm 1.75$ & $-21.68 \pm 2.49$ \\
& $\mathrm{CuFeS}_{2}$ & $-28.08 \pm 1.79$ & $\mathrm{ND}$ & $22.59 \pm 1.42$ & $\mathrm{ND}$ \\
\hline & $\mathrm{PbS}$ & $-17.59 \pm 5.28$ & $8.63 \pm 0.94$ & $\mathrm{ND}$ & $\mathrm{ND}$ \\
10 & $\mathrm{ZnS}$ & $14.40 \pm 0.83$ & $-15.29 \pm 1.52$ & $\mathrm{ND}$ & $\mathrm{ND}$ \\
& $\mathrm{CuFeS}_{2}$ & $4.94 \pm 2.33$ & $16.99 \pm 1.39$ & $\mathrm{ND}$ & $\mathrm{ND}$ \\
\hline
\end{tabular}

${ }^{* 1}$ Molar ratio $\left(\mathrm{H}_{2} \mathrm{O}_{2}\right.$ :mineral $)$

${ }^{* 2}$ Not determined

ments. ${ }^{33,34)}$ Hence, for consistency with the floatability trend, the zeta potential of the mineral must negatively increase with increasing $\mathrm{H}_{2} \mathrm{O}_{2}$ molar ratio. In the present study, however, the $\mathrm{H}_{2} \mathrm{O}_{2}$ treatment positively accelerated the zeta potentials of both $\mathrm{PbS}$ and $\mathrm{CuFeS}_{2}$ at both initial $\mathrm{pH}$ levels. The positively increased zeta potential after surface oxidation was also observed for other sulfide minerals. ${ }^{3,35)}$ The zeta potential of $\mathrm{ZnS}$ exhibits more complicated behavior, becoming more negative after surface oxidation at both $\mathrm{pHs}$, apparently consistent with the floatability trend. However, a closer analysis reveals that the zeta potential trends cannot explain the $\mathrm{ZnS}$ floatability results. Specifically, at initial $\mathrm{pH} 3$, the zeta potential of $\mathrm{ZnS}$ is almost constant (ca. $-20 \mathrm{mV}$ ) over the investigated range of molar ratios (0.5-2.0). This result cannot support the obvious decrease in $\mathrm{ZnS}$ floatability from $\sim 80 \%$ 
to $\sim 60 \%$ over the same range of molar ratios. Moreover, whereas the zeta potential was less negative in $\mathrm{ZnS}$ treated with 2.0 molar ratio $(-21.7 \mathrm{mV})$ than in untreated $\mathrm{CuFeS}_{2}$ $(-28.1 \mathrm{mV})$, the floatability was much lower for $\mathrm{ZnS}(\sim 55 \%)$ than for $\mathrm{CuFeS}_{2}(\sim 99 \%)$. This clearly excludes electrostatic force as a critical factor in our case. Note that the physico-chemical conditions (particle size, and the physical conditions and solution chemistry of the flotation test system) were almost identical in the flotation tests of all minerals. A similar trend for $\mathrm{ZnS}$ appears at initial $\mathrm{pH} 10$ (i.e., the zeta potential increases after surface oxidation and the floatability is higher for untreated $\mathrm{PbS}$ than for $\mathrm{ZnS}$ treated with 0.5 molar ratio). Therefore, we conclude that changes in the electrostatic force triggered by $\mathrm{H}_{2} \mathrm{O}_{2}$ addition cannot sufficiently explain the observed floatability changes.

To test whether the floatability was affected by the hydrophobic force, which responds to mineral hydrophobicity changes, the hydrophobicity was measured by the contact angle technique. The results are shown in Table 3 . The changes in contact angle and floatability corresponded for all minerals at both initial $\mathrm{pH}$ levels. In pure $\mathrm{PbS}$, which most sensitively reacted with $\mathrm{H}_{2} \mathrm{O}_{2}$, the contact angle was approximately $127.1^{\circ}$ at $\mathrm{pH} 3$. In contrast, the contact angle could not be measured at the lowest $\mathrm{H}_{2} \mathrm{O}_{2}$ addition (0.5 molar ratio), confirming a hydrophilic $\mathrm{PbS}$ surface. The contact angle of $\mathrm{ZnS}$ gradually decreased from $126.1^{\circ}$ to $110.9^{\circ}$ with increasing molar ratio, consistent with the floatability of this mineral ( $\sim 98.6-59.1 \%$ over the same molar ratio range). The contact angle of $\mathrm{CuFeS}_{2}$ at 0.5 molar ratio was approximately $115.3^{\circ}$, between that of $\mathrm{PbS}$ and $\mathrm{ZnS}$, and correspondent with the floatability trends. At pH 10, the three minerals were very sensitive to $\mathrm{H}_{2} \mathrm{O}_{2}$ content, and their contact angles were not measured even at 0.5 molar ratio, confirming their hydrophilic surfaces. This result accords with the surface mineralogy change investigated in subsection 3.2 (i.e., that oxygen-associated species with greater polarity reduce the floatability and also the contact angle). Interestingly, at floatabilities below $\sim 50 \%$, the contact angles of the mineral samples decreased too abruptly for measurement. This sharp decrease may reflect the close correlation between floatability and the sulfide fraction on the mineral surface, which directly affects the contact angle. This assumption should be verified in further study.

Table 3 Contact angles of $\mathrm{PbS}, \mathrm{ZnS}$, and $\mathrm{CuFeS}_{2}$ treated with various $R_{\mathrm{m}}$ at initial $\mathrm{pH}$ of 3 and 10 . The measurements were carried out under equilibrium conditions (see Fig. 2).

\begin{tabular}{cccccc}
\hline \multirow{2}{*}{$\mathrm{pH}$} & \multirow{2}{*}{ Mineral } & \multicolumn{4}{c}{$R_{\mathrm{m}(-)^{* 1}}$} \\
\cline { 3 - 6 } & $\mathrm{PbS}$ & $127.1^{\circ}$ & N.M. $^{* 2}$ & N.M. & N.M. \\
\hline \multirow{2}{*}{3} & $\mathrm{ZnS}$ & $126.1^{\circ}$ & $125.6^{\circ}$ & $120.9^{\circ}$ & $110.9^{\circ}$ \\
& $\mathrm{CuFeS}_{2}$ & $126.6^{\circ}$ & $115.3^{\circ}$ & N.M. & N.M. \\
\hline \multirow{2}{*}{10} & $\mathrm{PbS}$ & $125.4^{\circ}$ & N.M. & N.M. & N.M. \\
& $\mathrm{ZnS}$ & $126.7^{\circ}$ & N.M. & N.M. & N.M. \\
& $\mathrm{CuFeS}_{2}$ & $128.7^{\circ}$ & N.M. & N.M. & N.M. \\
\hline
\end{tabular}

${ }^{* 1}$ Molar ratio $\left(\mathrm{H}_{2} \mathrm{O}_{2}\right.$ :mineral $)$

${ }^{* 2}$ Not measurable

\section{Conclusions}

This study investigated the correlation between floatability and the surface property changes in three representative sulfide minerals after reaction with varying amounts of $\mathrm{H}_{2} \mathrm{O}_{2}$. The core outcomes are summarized below:

1. The oxidation levels on the mineral surface in equilibrium depended on mineral type; $\mathrm{PbS}$ was most sensitive to $\mathrm{H}_{2} \mathrm{O}_{2}$, followed by $\mathrm{CuFeS}_{2}$ and $\mathrm{ZnS}$. The $\mathrm{H}_{2} \mathrm{O}_{2}$ reaction caused the sulfide species that initially resided on the sulfide mineral surface to change to sulfate or hydroxyl species. The oxidation levels of mineral surface as well as the distributions and relative amounts of these altered species were also affected by initial $\mathrm{pH}$.

2. For all mineral types and at both initial $\mathrm{pH}$ levels, the floatability decreased with increasing $\mathrm{H}_{2} \mathrm{O}_{2}$ content. The decreased floatability with increasing $\mathrm{H}_{2} \mathrm{O}_{2}$ content corresponded with the decreased contact angle over the same range of $\mathrm{H}_{2} \mathrm{O}_{2}$ molar ratios, which was closely related to the hydrophobicity of the mineral surfaces.

\section{Acknowledgements}

This work was supported by the National Research Council of Science \& Technology (NST) grant by the Korea government (MSIP) (No.CRC-15-06-KIGAM) and the Korea Energy and Mineral Resources Engineering Program (KEMREP).

\section{REFERENCES}

1) D. Feng and C. Aldrich: Miner. Eng. 12 (1999) 721-731.

2) J. Leppinen, V. Hintikka and R. Kalapudas: Miner. Eng. 11 (1998) 3951.

3) D. Fullston, D. Fornasiero, J. Ralston: Colloid Surface A. 146 (1999) 113-121.

4) T. Healy, M. Moignard, M. Fuerstenau: Flotation. AM Gaudin Memorial Volume (MC Fuerstenau, Ed, 1976) p. 275.

5) B. A. Wills, T. Napier-Munn: Wills' mineral processing technology: an introduction to the practical aspects of ore treatment and mineral recovery (Butterworth-Heinemann, 2015) p. 267-268.

6) E. G. Kelly, D. J. Spottiswood: Introduction to mineral processing (1982) p. 101

7) J. Ralston: Miner. Eng. 7 (1994) 715-735.

8) T. Harvey and W. Yen: Miner. Eng. 11 (1998) 1-21.

9) J. Choi, K. Park, J. Hong, J. Park and H. Kim: Mater. Trans. 54 (2013) 2291-2296.

10) J. Choi, E. Lee, S.Q. Choi, S. Lee, Y. Han and H. Kim: Chem. Eng. J. 285 (2016) 207-217.

11) N. Ahmed and G. Jamson: Min. Proc. Ext. Met. Rev. 5 (1989) 77-99.

12) Y. Mu, Y. Peng and R.A. Lauten: Miner. Eng. 96-97 (2016) 143-156.

13) R.-Z. Liu, W.-Q. Qin, J. Fen, X.-J. Wang, P. Bin, Y.-J. Yang and C.-H. Lai: T Nonferr. Metal. Soc. 26 (2016) 265-271.

14) R. Rath and S. Subramanian: Int. J. Miner. Process. 57 (1999) 265-283.

15) B. Tapley and D. Yan: Miner. Eng. 15 (2003) 1217-1220.

16) Q. Liu and J. Laskowski: Int. J. Miner. Process. 27 (1989) 147-155.

17) C.-H. Park and H.-S. Jeon: Mater. Trans. 51 (2010) 1367-1369.

18) A.J. Nooshabadi and K.H. Rao: Int. J. Miner. Process. 157 (2016) 8997.

19) P. Huang, M. Cao and Q. Liu: Miner. Eng. 46-47 (2013) 45-51.

20) R. Pugh: Int. J. Miner. Process. 25 (1989) 101-130.

21) M. Von Smoluchowski : Phys. Chem. (Muenchen, Ger.). 92 (1917) 129-168.

22) J. Choi, W. Kim, W. Chae, S.-B. Kim and H. Kim: Mater. Trans. 53 (2012) 2191-2194 
23) P. de Donato, M. Kongolo, O. Barres, J. Yvon, F. Enderle, E. Bouquet, M. Alnot and J. Cases: Powder Technol. 105 (1999) 141-148.

24) I. Chernyshova: J. Electroanal. Chem. 558 (2003) 83-98.

25) S. Rajendran, S.P. Sridevi, N. Anthony, A.J. Amalraj and M. Sundaravadivelu: Anti-Corros. Methods Mater. 52 (2005) 102-107.

26) A. Pramanik, S. Maiti and S. Mahanty: Dalton Trans. 44 (2015) 14604 14612

27) A.V. Nguyen, D.-A. An-Vo, T. Tran-Cong, G.M. Evans: Int. J. Miner. Process. 156 (2016) 75-86.

28) T. Miettinen, J. Ralson and D. Fornasiero: Miner. Eng. 23 (2010) 420 437.
29) J. Choi, S.Q. Choi, K. Park, Y. Han and H. Kim: Int. J. Miner. Process. 146 (2016) 38-45.

30) R.-H. Yoon and L. Mao: J. Colloid Interface Sci. 181 (1996) 613-626.

31) S. Lu: Colloids Surf. 57 (1991) 73-81.

32) R.-H. Yoon: Int. J. Miner. Process. 58 (2000) 129-143.

33) A.M. Elmahdy, M. Mirnezami and J.A. Finch: Int. J. Miner. Process. 89 (2008) 40-43.

34) P. Saulnier, J. Lachaise, G. Morel and A. Graciaa: J. Colloid Interface Sci. 182 (1996) 395-399.

35) G. Fairthorne, D. Fornasiero and J. Ralston: Int. J. Miner. Process. 49 (1997) 31-48. 